\title{
THE MOTIVATIONS TO PARTICIPATING TREKKING ACTIVITIES: ADANA CASE
}

\author{
Erdinç Balli ${ }^{1}$ \\ Meltem Canoğlu
}

\begin{abstract}
The aim of this study is to determine the profile of the trekking participants and their motivation for participating to trekking activities, which is a kind of nature- based and adventure tourism. Questionnaire technique has been utilized as the data gathering method and for this purpose „Recreation Experience Preference Scalee, has been used in this study. The sample consists of 324 individuals participated to the trekking within nature- based activities associations in Adana, Turkey. Descriptive statistic methods are used for evaluations and representation of data. As a result of this study we found that majority of the participants are male $(\% 53,7)$, between $35-44$ years old $(\% 30,6)$, married $(\% 51,2)$, graduated from university $(\% 64,8)$, have been attending for $1-5$ years $(\% 41,7)$, participate to trekkings 3 or 4 times a year $(\% 41,7)$, and usually prefer to joint the activities with friends $(\% 60,8)$. The results of survey also show that the first ten reasons to motivate the individuals to participate to trekking are; "physical rest, slow down mentally, tranquility,escape role overloads, escape daily routine, escape crowds, exercisephysical fitness, independence, privacy and nostalgia".
\end{abstract}

Key words: Trekking, nature-based tourism, tourist motivation

\section{INTRODUCTION}

Among the alternatives of the tourism industry nicknamed as the chimneyless industry in the 21st century, especially natural tourism have gained momentum in recent years. Many tourism activities are done within the scope of nature tourism. One of them is trekking. Trekking is the combination of hiking and walking activity in nature, rural and undeveloped area and also known as the act of making a long journey across difficult country on foot, usually for pleasure. Why make people a long and difficult journey in nature on foot? What motivates people to participating in those activities? The aim of this study is to determine the profile of the trekking participants and their reasons for participating to trekking activities.

Although the characteristics and motivations of tourist more widely understood, there is less empirical research into the motivations of trekking participants and very little market information on their characteristics, preferences and motivations. This paper will help to understand trekking participants and will make new contributions to the literature on them. By understanding the motives of trekking participants, activity operators can better tailor their offerings to particular tourist needs and can specifically

\footnotetext{
${ }^{1}$ Assistant Professor, Cukurova University School of Karataş Tourism and Hotel Management, Karataş-Adana, Turkey. e-mail: eballi@cu.edu.tr
} 
benefit from these issues with regards to market segmentation, product development, service quality evaluation and image development.

\section{LITERATURE REVIEW}

People's motivation to behave is an interesting issue to explore, especially in understanding leisure motivation. Motivation is a state of need or condition that drives an individual toward certain types of action that are seen as likely to bring satisfaction (Mountinho, 2000). Motivation is the driving force which compels an individual to take action (Schiffman \& Kanuk, 2004). This implies that motivation moves a person to do something (Ryan \& Deci, 2000). Travel motivation relates to why people travel (Hsu \& Huang, 2008). Tourist motivation, therefore, can be defined as "the global integrating network ofbiological and cultural forces which gives value and direction to travel choices, behaviour and experience" (Pearce, Morrison \& Rutledge, 1998).

Motivations for travel cover a broad range of human behavior and human experiences. A list of travel motivations might include: relaxion, excitement, social interaction with friends, adventure, family interaction, status, physical challenges and escape from routine or stress (Esichaikul, 2012) . McIntosh and Goeldner (1986) identified four motivators of travel; physical motivators, cultural motivators, interpersonal motivators, and, status and prestige motivators. By analyzing motivation in tourism we can determine several types of motivations, based on which forms of tourism were developed. Physical motivations derived in tourism recreation, sport, health, cultural motivations derived in cultural tourism, spiritual motivations derived in religious tourism, pilgrimage etc.

Work activity and other routines associated with the life style of modern society, have given rise to increasing demand for different forms of tourism such as nature- based tourism. Public concern for nature, ecology and the environment in general has created growing interest in those forms of tourism in which there is greater interaction with natural spaces (Karmakar, 2011). According to Eagles and Cascagnette (1995), nature tourists are individuals who travel with the intent of observing, experiencing and learning about nature. The purposes of nature tourists' visits seem to be enjoying, admiring and studying the natural environment and appreciating the cultural values of the areas (Subbiah and Kannan, 2012). Nature-based tourism implies different concepts such as adventure tourism. Adventure tourism is concerned, these activities can be said to involve physical and social risks, the search for intense, new experiences and social interaction, thoughts and feelings, an escape from personal situations and routines (Villalobos-Céspedes et al., 2012).

Trekking is one of the fastest growing activities under nature tourism especialy under adventure tourism. Trekking as a recreative activity is mainly done in outdoor, in natural areas and protected areas. Trekking is practiced in difficult terrain and climate, requiring specialized equipment, clothing and food, implying connotations of risk, jeopardy, and wilderness (Weber, 2001; Buckley, 2006). Trekking refers to travel by 
foot through remote destinations that are, in most cases, inaccessible and unknown to the visitor. It is often associated only with mountains, but it must be emphasized that one may distinguish eight types of trekking, these are: mountain, desert, tropical, glacial, polar, river, swamps and volcanic trekking (Różycki \& Dryglas, 2014). Trekking is the combination of hiking and walking activity in nature, rural and undeveloped area and also known as the act of making a long journey across difficult country on foot, usually for pleasure. Why make people a long and difficult journey in nature on foot? What motivates people to participating in those activities?

There are different reasons or motivation factors to participating in trekking activities. Trekking is as an outdoor activity, several related studies help understanding of trekking participants' reasons (Driver, 1983; Pintrich, 2000, Ibrahim \& Cordes, 2002; Ardahan \& Mert, 2013). According to Driver's (1983) study, the reasons for participating ; a) need for achievement/ stimulation b) autonomy/leadership (c) enjoy risk taking, d) use equipment, e) to be together with own family f) to be with similar people $\mathrm{g}$ ) to meet new people $\mathrm{h}$ ) learning new things and natüre i) enjoy nature $\mathrm{k}$ ) to be more creativity, 1) nostalgia, m) physical fitness, n) physical rest, o) escape personal-social pressures $\mathrm{p}$ ) escape physical pressure q) social security, r) escape family, s) teaching-leading others t) risk reduction and to $(\mathrm{u})$ fell better temperature.

In another study which conducted on Turkish people by Ardahan (2011), the reasons for that were founded as; (a) physical and mental fitness, (b) physical and mental rehabilitation, (c) to improve oneself and to learn new skills, (d) tempting things in nature, (e) to be a fighter and to revolt, (f) to have new social relations and (g) to make new friends, (h) to observe people, (i) to improve social status and take social power, (j) recognition and to be recognized, $(\mathrm{k})$ to nonnock and get out of boredom, and (1) to meet a celebrity in this activity.

\section{METHODOLOGY}

In the study, scanning model has been preferred to identify the motivations to participating trekking activities. Questionnaire technique has been utilized as the data gathering method. The questionnaire consisted of 2 sections. The first part of the survey contained questions relating to demographic characteristic of participants. In the second section of the questionnaire included reason for participating trekking activity. For this purpose „Recreation Experience Preference Scale ${ }^{e e}$ by Driver (1983) , has been used in this study. A five-point Likert scale was used and the range covers (1: definitely disagree, 5: definitely agree).

An electronic questionnaire form developed to gather data suitable for the purpose of this study was sent to members of natur-based activities associations in Adana between 10'th March, 2016-1'st July, 2016. Through word of mouth people were encouraged to visit the website and respond to the questionnaire. The sample consists of 324 individuals participated to the trekking within nature- based activities associations in 
Adana, Turkey. After the data is collected and made ready for the analysis, a variety of simple statistical medhods was used in a way that allows descriptive analysis to be carried out. In the data evaluation phase the following statistical definitions were used:frequency (f), percentage (\%), mean (M) and standard deviation (Ss).

\section{FINDINGS}

The demografik characteristik of 324 trekking participants are presented in Table 1 . According to the result, 53,7\% respondents were males and 46,3\% were females (see Table 1). When we look at the age group of the participants, $30,6 \%$ of them belong to the category 35 to 44 years old, closely followed by 25 to 34 years old $(28,7 \%), 15$ to $24(21,6 \%), 45$ to 54 and +55 get $19,1 \%$ both.

Table 1. Demografic characteristics of Participants $(n=324)$

\begin{tabular}{|c|c|c|}
\hline Gender of Participants & Frequency & Percent \\
\hline Female & 150 & 46,3 \\
\hline Male & 174 & 53,7 \\
\hline Age Group of Participants & Frequency & Percent \\
\hline $15-24$ & 70 & 21,6 \\
\hline $25-34$ & 93 & 28,7 \\
\hline $35-44$ & 99 & 30,6 \\
\hline $45-54$ & 48 & 14,8 \\
\hline 55 and over & 14 & 4,3 \\
\hline Marital status of Participants & Frequency & Percent \\
\hline Married & 166 & 51,2 \\
\hline Single & 158 & 48,8 \\
\hline Education Level of Participants & Frequency & Percent \\
\hline Secondary school and its under & 17 & 5,2 \\
\hline High scholl & 44 & 13,6 \\
\hline Undergraduate & 142 & 43,8 \\
\hline Bachelor & 103 & 31,8 \\
\hline Master or Doctoral Degree & 18 & 5,6 \\
\hline Trekking Experience of Participants & Frequency & Percent \\
\hline$<1$ year & 98 & 30,2 \\
\hline $1-5$ years & 135 & 41,7 \\
\hline $6-10$ years & 59 & 18,2 \\
\hline$>11$ years & 32 & 9,9 \\
\hline Frequency of Participation & Frequency & Percent \\
\hline once a year & 87 & 26,9 \\
\hline 3 or 4 times a year & 135 & 41,7 \\
\hline once a month & 54 & 16,7 \\
\hline 3 or 4 times a month & 48 & 14,8 \\
\hline Participating with & Frequency & Percent \\
\hline Alone & 42 & 13,0 \\
\hline with family members & 85 & 26,2 \\
\hline with friends & 197 & 60,8 \\
\hline
\end{tabular}


Regarding the marital status, it appears that the respondents are quite spread, almost equally. $51,2 \%$ of them are married and $48,8 \%$ are single.It is seen that $\% 43,8$ of the participants had an undergraduate education, $\% 31,8$ of the participants had an bachelor degree, \% 13,6 of the participants had an highschool education, \% 5,6 of the participants had an master or doctoral degree and \% 2,2 of the participants had an Secondary school and its under education.

Furthermore, $41.8 \%$ of participants have 1 to 5 years trekking experience, followed by less than 1 year $30,2 \%$, by $6-10$ years $18,2 \%$, and by over 11 years $9,9 \%$, respectively. $41,7 \%$ of individual participate to trekkings 3 or 4 times a year, 26,9\% once a year, $16,7 \%$ once a month and $14,8 \%$ of them 3 or 4 times a month. A total of $60,8 \%$ of the respondents participate to trekkings with friends, $26,2 \%$ with their families and $13 \%$ alone. The values of means and standard deviations for each item in the study ${ }^{\text {ee }} \mathrm{s}$ questionnaire are presented in Table 2.

Table 2. Descriptive Statistics Associated with reasons to motivate the individuals to participate to trekking

\begin{tabular}{|l|l|l|}
\hline \multicolumn{2}{|c|}{ Descriptive Statistics } \\
\hline \multicolumn{2}{|l|}{ Mean } & Std. Dev. \\
\hline To relax physically & 4,636 & 0,6868 \\
\hline To have your mind move at a slower pace & 4,589 & 0,72059 \\
\hline To experience tranquility & 4,583 & 0,73554 \\
\hline To have a change from your daily routine & 4,574 & 0,72381 \\
\hline To avoid everyday responsibilities for awhile & 4,574 & 0,76134 \\
\hline To be away from crowds of people & 4,537 & 0,76404 \\
\hline To keep physically fit & 4,486 & 0,78726 \\
\hline To feel your independence & 4,482 & 0,77677 \\
\hline To be alone & 4,482 & 0,80033 \\
\hline To think about good times you've had in the past & 4,458 & 0,80954 \\
\hline To experience excitement & 4,241 & 0,93309 \\
\hline To be with respectful people & 4,176 & 0,99063 \\
\hline To learn more about things [here/there]. & 4,157 & 0,98435 \\
\hline To develop your skills and abilities & 4,13 & 1,03881 \\
\hline To test your endurance & 4,083 & 1,048 \\
\hline To meet other people in the area & 4,075 & 0,95114 \\
\hline To learn more about nature & 3,907 & 1,09491 \\
\hline To be creative & 3,889 & 0,94754 \\
\hline To be with [others/people] who enjoy the same things you do & 3,889 & 1,04984 \\
\hline To tell others about the trip & 3,851 & 1,06277 \\
\hline To test your abilities & 3,833 & 1,0946 \\
\hline To think about your personal values & 3,722 & 1,02749 \\
\hline
\end{tabular}




\begin{tabular}{|l|l|l|}
\hline To develop a sense of self-pride & 3,667 & 1,13214 \\
\hline To get to know the lay of the land & 3,491 & 1,16046 \\
\hline To be with friends & 3,477 & 1,17518 \\
\hline To do something with your family & 3,232 & 1,20067 \\
\hline To view the scenic beauty & 3,176 & 1,13073 \\
\hline To be away from the family for awhile & 2,944 & 1,17112 \\
\hline To show others you can do it & 2,811 & 1,21991 \\
\hline To enjoy the smells and sounds of nature & 2,75 & 1,21236 \\
\hline
\end{tabular}

„To relax physically“was the highest mean (3.68; SD: 0, 6868) indicating its importance from the point of view of the sample individuals while To enjoy the smells and sounds of nature"was the least mean (2,75, SD: 1.212) indicating less importance upon the sample individuals. The further findings of the research reveal that „to relax physically“ (M: 4,636), „to have your mind move at a slower pace“ (M:4,589), „to experience tranquility" $(M: 4,583)$, "to have a change from your daily routine“ $(M: 4,574)$,to avoid everyday responsibilities for awhile $(M: 4,574)$, "to be away from crowds of people“ $(M: 4,537)$, ,to keep physically fit" $(M: 4,486)$, „to feel your independence“ $(M: 4,482)$, ,to be alone“ $(M: 4,482)$, ,to think about good times you've had in the past" $(M: 4,458)$, „to experience excitement" $(4,241)$, „to be with respectful people“ $(M: 4,176)$, „to learn more about things there]“ $(M: 4,157)$, „to develop your skills and abilities" $(M: 4,13)$, „to test your endurance“ $(M: 4,083)$, „to meet other people in the area" $(M: 4,075)$, ,to learn more about nature" $(M: 3,907)$, ,to be creative" (M: 3,889), ,to be with [others/people] who enjoy the same things you do" (M: 3,889), „to tell others about the trip" $(M: 3,851)$, „to test your abilities“ $(M: 3,833)$, „to think about your personal values“ $(M: 3,722)$, „to develop a sense of self-pride“ $(M: 3,667)$, „to get to know the lay of the land“ $(M: 3,491)$, „to be with friends" $(M: 3,477)$, „to do something with your family“ (M: 3,232), „to view the scenic beauty“ (M: 3,176), „to be away from the family for awhile“ $(M: 2,944)$ and „to show others you can do it" (M:2,811), respectively.

\section{CONSULATION}

Studying tourist motivation has always been an important factor for tourism management. The ways of expressing and the changes that develop in time in tourist motivations directly influence tourism demand and supply. Understanding specific tourist"s motivations can help understanding the needs, goals and preference of the tourists and help planning better products and services more efficient in marketing communication and managing visitor attractions.

In this study is aimed to to determine the profile of the trekking participants -in another words, trekking tourist- and their motivation for participating to trekking activities This study in which the exploratory analysis of the data has been given shows some facts 
abaut the charecteristik of trekking participants. The findings of this study indicate that majority of the participants are male (\% 53,7), between 35-44 years old $(\% 30,6)$, married $(\% 51,2)$, graduated from university $(\% 64,8)$, have been attending for $1-5$ years $(\% 41,7)$, participate to activities $3-4$ times a year $(\% 41,7)$ and usually prefer to joint the activities with friends $(\% 60,8)$. The results of survey also show that the first ten reasons to motivate the individuals to participate to trekking are; "physical rest, slow down mentally, tranquility, escape role overloads, escape daily routine, escape crowds, exercise-physical fitness, independence, privacy and nostalgia”.

\section{REFERENCES}

1. Buckley, R. (2006) Adventure tourism. UK: Biddles Ltd.

2. Ibrahim, H., \& Cordes, K.A., (2002) Outdoor recreation, enrichment for a lifetime. 2. Edt., IL:.Sagamore Pub.

3. McIntosh, R.W. \& Goeldner, C.R. (1986), Tourism: principles, practices and philosophies. 5th ed. New York: .John Wiley \& Sons,

4. Mountinho L, (2000). Strategic management in tourism. Newyork: CABI Pub.

5. Pearce, P., A. M. Morrison., and J. L. Rutledge (1998). Tourism: Bridges Across Continents. Sydney: McGraw-Hill.

6. Schiffman, L. G., and Kanuk L. L. (2004). Consumer behavior. 8th Ed. New Jersey: Prentice Hall.

7. Journal Article

8. Ardahan, F. \& Mehmet M. (2013). The validity and reliability of motivational factors scale and the benefits scale of participating in trekking activities for Turkish population. Journal of Human Sciences 10.2, 338-355.

9. Eagles, P.F. and Cascagnette, J.W. (1995) Canadian ecotourists: who are they?. Tourism Recreation Research, 20(1): 22-28.

10. Driver, B. L. (1983). Master list of items from Recreation Experience Preference scales and domain. Unpublished document. Fort Collins, CO: USDA Forest Service, Rocky Mountain Forest and Range Experiment Station.

11. Esichaikul, Ranee. "Travel motivations, behavior and requirements of European senior tourists to Thailand." PASOS, Revista de Turismo y Patrimonio Cultural 10.2 (2012): 47-58.

12. Hsu, C.H. C. and Huang S. "Travel motivation: A critical review of the concept's development." Tourism management: Analysis, behaviour and strategy (2008): 1427.

13. Karmakar, M. (2011). Ecotourism and its impact on the regional economy - a study of north Bengal (India). Tourismos, Vol. 6, No.1, pp.251-270.

14. Pintrich, P.R. (2000). An Achievement Goal Theory Perspective on Issues in Motivation Terminology, Theory and Research. Contemporary Educational Psychology, 25, 92-104. 
15. Różycki, P., \& Dryglas, D. (2014). Trekking as a phenomenon of tourism in the modern world. Acta Geoturistica vol, 5(1), 24-40.

16. Subbiah, K. \& Kannan, S. (2012) The management strategies of ecotourism development in Papua New Guinea. International Journal of Economics Business and Management Studies, 1(3):114-120.

17. Villalobos-Céspedes, D., Galdeano-Gómez, E., \& Tolón-Becerra, A. (2012). International demand for nature-based tourism in Costa Rica: socio-demographic and travel indicators. Tourismos, 7(1), 269-287.

18. Weber, K. (2001) Outdoor Adventure Tourism: A Review of Research Approaches. Annals of Tourism Research 28, 360-377.

19. Conference proceeding:

20. Ardahan, F. (2011). The Profile of The Turkish Mountaineers and Rock Climbers: The Reasons and The Carried Benefits for Attending Outdoor Sports and Life Satisfaction Level, 8 th International Conference Sport and Quality of Life, Brno/Czech Republic 